\title{
Exergy and Energy Analysis of a Dry Steam Power Plant with Heller Condenser
}

\author{
Authors: D. Tempesti*1 ${ }^{1}$, G. Manfrida ${ }^{2}$, L. Madiai $^{3}$ \\ Department of Industrial Engineering, University of Florence \\ Centro Didattico Morgagni, Viale Morgagni 40-44, 50133 Italy, Florence, \\ E-mail: ${ }^{1}$ duccio.tempesti@ unifi.it, ${ }^{2}$ manfrida@ unifi.it, ${ }^{3}$ luca.madiai@gmail.com
}

\begin{abstract}
Geothermal power plants are widely used in the Larderello region, Tuscany, due to its favourable geological characteristics. The geothermal fluid available at Larderello contains about $95 \%$ of steam at relatively high temperature $\left(200^{\circ} \mathrm{C}\right)$, and about $5 \%$ of non-condensable gases, mainly carbon dioxide. Due to its thermodynamic properties, the geothermal fluid is currently used in a Dry Steam power plant, where it is directly expanded in turbine. In this paper, some modifications to the structure of the plant are proposed and the plant is modelled using the software EES ${ }^{\circledR}$. In the model, the geo-fluid flow is ideally separated in two flows, respectively water vapour flow and carbon dioxide flow, treating separately the expansion and the compression processes. Energy and exergy analysis are performed, and the results show a good agreement with the results presented in the literature, where the geo-fluid is modelled as a single flow. Since the water flow rate for the condensing process is significant, the possibility of recovering work through a Heller system is considered. The results show that $85 \%$ of the power required for the pumping of the condensing water can be provided by this Heller system.
\end{abstract}

\section{Keywords: Dry steam power plant, geothermal energy, exergy analysis, Heller condenser.}

\section{Introduction - Exergy Analysis of Geothermal Power Plants}

The first geothermal power plant in the world was operated in 1904 in Larderello, Tuscany, and it was a drysteam plant. Nowadays, although there are only two major dry-steam fields in the world (Larderello and The Geysers, in northern California) more than 60 units of this type are in operation (12\% of all geothermal plants, data at May 2007) [1]. This type of power plants is very simple and it is usually less expensive than the flash steam plants. The geothermal fluid available at Larderello can be considered as a dry steam, since it contains about $95 \%$ of steam at relatively high temperature $\left(200^{\circ} \mathrm{C}\right)$, and about $5 \%$ of noncondensable gases (NCG), mainly carbon dioxide [1].

Exergy analysis has proven to be a powerful tool in the thermodynamic analysis of energy systems [2-6]. This also applies to performance evaluation of geothermal power plants. The temperatures of geothermal fluids are relatively low, so the First Law efficiencies of geothermal power plants are also inherently low. Consequently, the difference between the First Law efficiency of a good performing and that of a poorly performing geothermal power plant located at similar sites is small [7].

Bodvarrson and Eggers [8] used the concept of exergy analysis for assessment of geothermal power plants. They tabulated the exergy of saturated water for sink conditions of different temperatures. DiPippo and Marcille [9] have shown the advantage of basing efficiency calculations and, then, comparisons between plants on the Second Law of thermodynamics. Kanoglu [7] presented an exergy analysis of a dual-level binary geothermal power plant and illustrated the exergy destruction throughout the plant by using an exergy flow diagram. DiPippo [10] studied the exergetic performance of low-temperature geothermal binary power plants. The results show that binary plants can operate with very high exergy efficiencies even if the geothermal fluids are low-temperature and low-exergy. Exergetic efficiencies of $40 \%$ or greater have been achieved in certain plants with geo-fluids having specific exergies of $200 \mathrm{~kJ} / \mathrm{kg}$ or lower. The main guideline leading to high exergy efficiency lies in the design of the heat exchangers to minimize the loss of exergy during heat transfer processes [10]. Yari [11] compared various types of binary cycle power plants fuelled by a geothermal fluid at high temperature (around $240^{\circ} \mathrm{C}$ ) through energy and exergy analysis. Coskun, Oktay and Dincer [12] performed a thermodynamic analysis of an operational 7.5 MWe binary geothermal power plant, through energy and exergy, using actual plant data. They evaluated eight performance-related parameters to assess the energetic and exergetic performances. Ganjehsarabi, Gungor and Dincer [13], carried out an exergy analysis of a binary geothermal power plant with $9.5 \mathrm{MW}$ net power output by using actual operational plant data to evaluate plant performance and pinpoint the locations of exergy destructions/losses.

Bettagli and Bidini [14] presented a specific energyexergy study of the geothermal fluid network in the area of Larderello-Valle Secolo-Farinello (Tuscany, Italy). They also carried out an exergy analysis of the dry-steam power plants of Larderello and Valle Secolo running at that time, in order to assess the global exergy performance of the geothermal systems.

Since many references have been found on exergy analysis on binary or flash geothermal power plant, while very few were found for dry-steam power plant, in this study the performance of geothermal dry-steam power plant is assessed, through energy and exergy efficiencies. When dealing with dry-steam power plant, the geothermal fluid is 
normally considered as saturated or superheated steam, neglecting the presence of gas ([1]; [14]). In our thermodynamic model, instead, the geothermal fluid is ideally separated in two flows, respectively water vapour flow and carbon dioxide flow, treating separately the expansion and the compression processes. The results of the energy and exergy analysis are compared with the results obtained in [14], where the geo-fluid is modelled as a single flow. The proposed thermodynamic model allows taking into consideration the chemical composition of the drysteam fluid and the effect on the overall performance of the system. Finally, a way to enhance the performance of the system is presented.

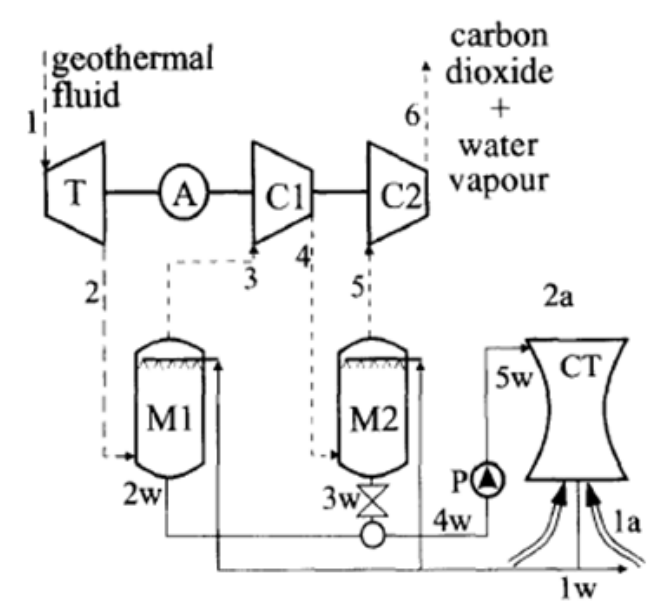

Fig. 1. Dry-steam power plant diagram [14].

\section{Dry-Steam Power Plant}

The general schematic of the power plant is shown in Figure 1 [14]. The geothermal fluid (mixture of dry steam and $\mathrm{CO}_{2}$ ) at point 1 expands directly in the turbine $\mathrm{T}$, producing work that powers the alternator A (for electricity production) and compressors $\mathrm{C} 1$ and $\mathrm{C} 2$ for the extraction of non-condensable gases, which are assumed composed only by $\mathrm{CO}_{2}$. At the end of the expansion (point 2) the fluid enters the first separator (or direct-contact condenser) M1, which operates well below the atmospheric pressure. A mixture of saturated steam and $\mathrm{CO}_{2}$ exits the separator in section 3, while the condensate, collected at the bottom, is brought to the cooling tower (point $2 \mathrm{w}$ ). The mixture of steam and $\mathrm{CO}_{2}$ passes through the compressor $\mathrm{C} 1$ and is routed to the second separator M2, which operates at a pressure higher than M1 pressure (but lower than atmospheric pressure). The $\mathrm{CO}_{2}$ is then extracted through the air compressor $\mathrm{C} 2$ and exhausted in the atmosphere at point 6 . The condensed water meets the stream coming from the first separator, and is pumped back to the cooling tower by the pump P.

\section{Thermodynamic Model}

In this work, a simple strategy of simulation is applied and the results are compared with those presented in [14]. The basic idea is to ideally separate the geo-fluid flow in two distinct streams, respectively water vapour and carbon dioxide. In this way, the expansion and the compression processes are ideally divided in two processes evolving in parallel. Figure 2 represents the schematic diagram used for the simulation. The geo-fluid flow rate in point 1 is ideally separated in two flows, point 2 and 3, which are respectively water vapor flow and carbon dioxide flow. The properties of point 2 and 3 are found using the partial pressures (Dalton's law) and the percentage fractions in mass $\mathrm{X}_{\mathrm{H} 2 \mathrm{O}}$ and $\mathrm{X}_{\mathrm{CO} 2}$. The temperature is assumed the same for points 1, 2 and 3. The same separation is done for both the compressors. The calculated points do not correspond to the real situation of the mixture: however, as energy and mass conservation is imposed at each mixing or separation node, the model should provide consistent results. The model was developed using Engineering Equation Solver $\operatorname{EES}^{\circledR}$ [15]. Table 1 reports the input data assumed in the model.

Table 1. Input Data to the Model.

\begin{tabular}{|c|c|}
\hline Ambient temperature $\left[{ }^{\circ} \mathrm{C}\right]$ & 25 \\
\hline Relative humidity & 0.6 \\
\hline Inlet pressure $p_{1}[\mathrm{bar}]$ & 5 \\
\hline Inlet temperature $\mathrm{T}_{1}\left[{ }^{\circ} \mathrm{C}\right]$ & 195 \\
\hline Inlet geothermal fluid flow rate $m_{1}[\mathrm{~kg} / \mathrm{s}]$ & 111.1 \\
\hline $\begin{array}{l}\text { Percentage in mass of } \mathrm{CO}_{2} \text { in the inlet } \\
\text { geothermal fluid }\end{array}$ & $5 \%$ \\
\hline $\mathrm{D} 1$ pressure $\mathrm{p}_{\mathrm{D} 1}[\mathrm{bar}]$ & 0.08 \\
\hline $\mathrm{D} 2$ pressure $\mathrm{p}_{\mathrm{D} 2}[\mathrm{bar}]$ & 0.272 \\
\hline NGC temperature at D1 outlet $\mathrm{T}_{12}\left[{ }^{\circ} \mathrm{C}\right]$ & 26 \\
\hline Water temperature at $\mathrm{D} 1$ outlet $\mathrm{T}_{16}\left[{ }^{\circ} \mathrm{C}\right]$ & 36.5 \\
\hline NGC temperature at $\mathrm{D} 2$ outlet $\mathrm{T}_{24}\left[{ }^{\circ} \mathrm{C}\right]$ & 33 \\
\hline Water temperature at $\mathrm{D} 2$ outlet $\mathrm{T}_{17}\left[{ }^{\circ} \mathrm{C}\right]$ & 33 \\
\hline Pressure drop at D1 outlet [bar] & 0.01 \\
\hline Pressure drop at D2 outlet [bar] & 0.012 \\
\hline $\mathrm{CO}_{2}$ removal efficiency of D1 & 0.726 \\
\hline $\mathrm{CO}_{2}$ removal efficiency of D2 & 0.911 \\
\hline Turbine isentropic efficiency & 0.85 \\
\hline Compressor isentropic efficiency & 0.80 \\
\hline Pump isentropic efficiency & 0.80 \\
\hline COOLING TOWER (CT) & \\
\hline Design tower exit temperature $\left[{ }^{\circ} \mathrm{C}\right]$ & 35 \\
\hline Water temperature at NDCT outlet $\mathrm{T}_{20}\left[{ }^{\circ} \mathrm{C}\right]$ & 25 \\
\hline
\end{tabular}

The separator is working at fixed temperature and pressure. All the $\mathrm{CO}_{2}$ is supposed to be extracted by D1 and D2 with the assumed removal efficiency (which depends on the sizing of the stripping tower). The separator removal efficiency is defined as the ratio between the flow rate of $\mathrm{CO}_{2}$ and the total flow rate extracted from the separator; for D1:

$\eta_{\text {sep }}=\frac{m_{9}}{m_{7}+m_{9}}$

A similar equation is used for the other separator D2. A natural-draft cooling tower (CT) is used to cool down the water returning from the separators. The CT performance depends on atmospheric conditions (i.e. temperature and relative humidity). Then, we calculate the range and approach of the CT. The range is calculated as the difference between the temperature of the cooling water returning from the condenser (i.e., point 19) and the temperature of the sub-cooled water in the CT drain reservoir (point 20), fixed at $25^{\circ} \mathrm{C}$ [14]. The CT approach is commonly defined as the difference between the temperature of the sub-cooled water (point 20) and the wet bulb temperature. The CT approach is usually estimated to be in a range of $5-10{ }^{\circ} \mathrm{C}$, however never less than $2.8^{\circ} \mathrm{C}$ [16]. The design exit temperature of air flow was set at $35^{\circ} \mathrm{C}$ according to environmental Italian regulations [17]. The effectiveness of the CT is defined as the ratio between the range and the difference between cooling water inlet temperature and ambient wet bulb temperature. 


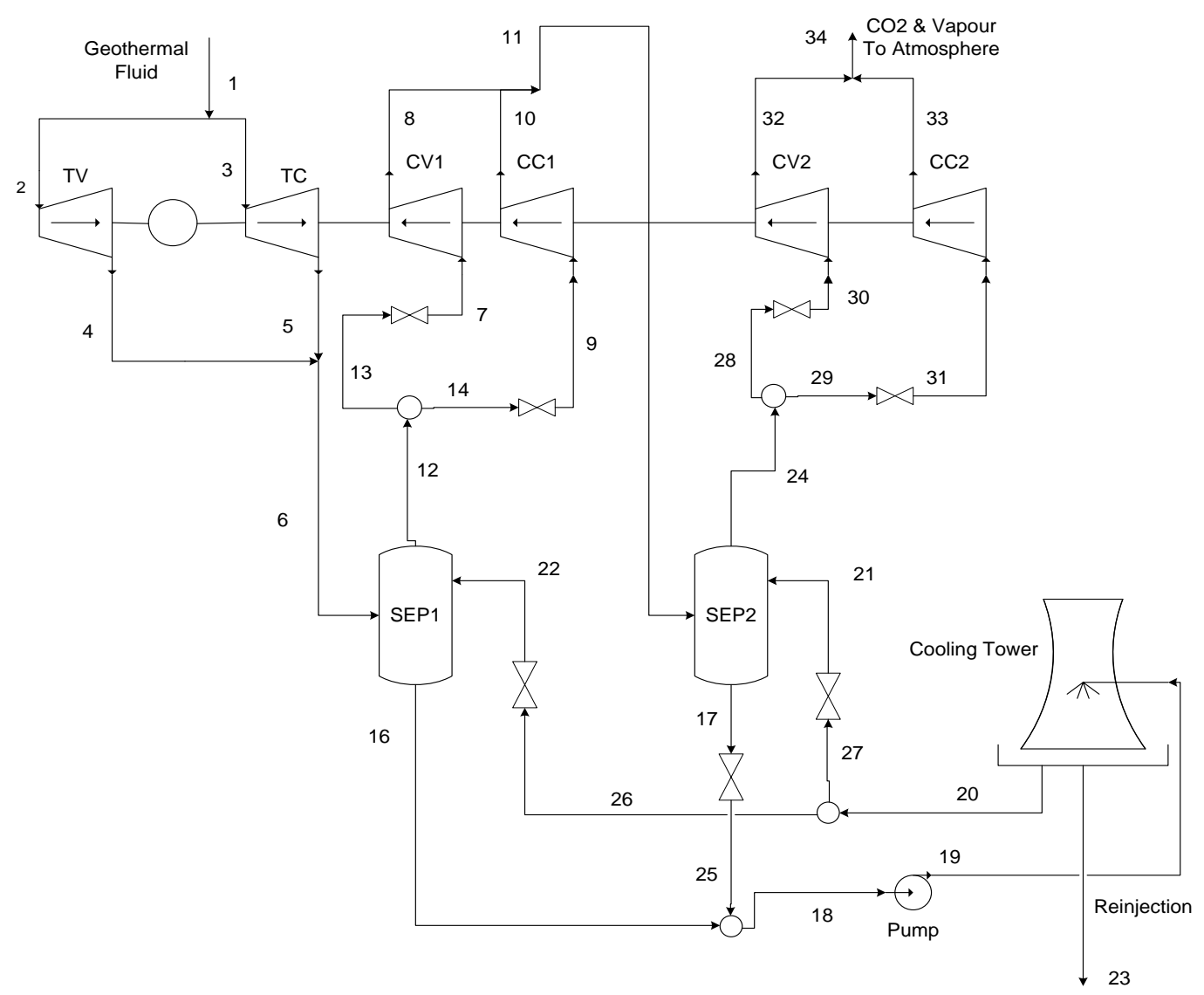

Figure 2. Modified schematic of the dry steam power plant.

\section{Performance Analysis}

The model allows calculating the main performance indicators of the power plant. The system efficiency is calculated by:

$\eta=\frac{W_{\text {net }}}{Q_{\text {geo }}}$

where $W_{\text {net }}$ is the net power output of the cycle and $Q_{\text {geo }}$ is the thermal power supplied by the geothermal resource, calculated as:

$Q_{g e o}=m_{1} h_{1}$

Where $h_{1}$ is the enthalpy of the geothermal fluid at system inlet (point 1). Some useful parameters were calculated, like the dimensionless ratio between the thermal power discharged $\mathrm{Q}_{\mathrm{CT}}$ and plant gross power $\mathrm{W}_{\mathrm{T}}$ :

HeatToPower $=\frac{Q_{C T}}{W_{T}}$

Also the geothermal consumption, which represents the amount of geothermal fluid needed to produce one $\mathrm{kWh}$, is calculated by:

Geo $_{\text {rate }}=\frac{m_{1} 3600}{W_{\text {net }}}$

The discrepancy of the results is explained with some missing data in the original reference, which were substituted by reasonable assumptions. Table 4 lists the temperature, pressure, mass flow rate, enthalpy, and entropy values of the system according to points shown in Figure 2.

Table 2. Dry Steam Model Results.

\begin{tabular}{lcc}
\hline & & {$[14]$} \\
\hline System efficiency $\eta[\%]$ & 18.8 & 19.2 \\
Thermal power input $Q_{\text {geo }}[\mathrm{kW}]$ & 301217 & 290316 \\
Net power output $W_{\text {net }}[\mathrm{kW}]$ & 56444 & 55805 \\
Heat To Power & 4.1 & 4.2 \\
Geothermal consumption $\mathrm{GeO}_{\text {rate }}$ & 6.8 & 7.2 \\
Cooling tower approach $T\left[{ }^{\circ} \mathrm{C}\right]$ & $14.2^{\circ} \mathrm{C}$ & n.a. \\
Cooling tower range $T\left[{ }^{\circ} \mathrm{C}\right]$ & 16.7 & n.a. \\
Cooling tower effectiveness $[\%]$ & 54 & n.a. \\
\hline
\end{tabular}

\section{Exergy Analysis}

The exergy analysis of the system was carried out following classical references [2-6]. The exergy input to the system is:

$E_{\text {in }}=E_{1}=m_{1}\left(\varepsilon_{1}-\varepsilon_{0}\right)=m_{1}\left(\left(h_{1}-h_{0}\right)-T_{0}\left(s_{1}-s_{0}\right)\right)$

where $\varepsilon_{0}$ is the exergy of the fluid (steam or carbon dioxide) at the reference state. This last is assumed at $25^{\circ} \mathrm{C}$ and 1.01325 bar. The exergy values were computed for all points of the cycle and they are reported in the last column of Table 3. The useful exergy is the power produced $\mathrm{W}_{\text {net }}$, so that the exergy efficiency is given by:

$\eta_{x D}=\frac{W_{\text {net }}}{E_{\text {in }}}$ 
Table 3. Model Results.

\begin{tabular}{|c|c|c|c|c|c|c|c|}
\hline $\begin{array}{l}\text { State } \\
\text { no. }\end{array}$ & $\begin{array}{c}\text { Mass } \\
\text { flow rate } \\
{[\mathrm{kg} / \mathrm{s}]}\end{array}$ & $\begin{array}{c}\text { Molar flow } \\
\text { rate } \\
{[\mathrm{kmol} / \mathrm{s}]}\end{array}$ & $\begin{array}{c}\text { Pressure } \\
{[\mathrm{kPa}]}\end{array}$ & $\begin{array}{c}\text { Temperature } \\
{\left[{ }^{\circ} \mathrm{C}\right]} \\
\end{array}$ & $\begin{array}{c}\text { Enthalpy } \\
{[\mathrm{kJ} / \mathrm{kg}]}\end{array}$ & $\begin{array}{c}\text { Entropy } \\
{[\mathrm{kJ} / \mathrm{kg} \mathrm{K}]}\end{array}$ & $\begin{array}{l}\text { Exergy } \\
{[\mathrm{kJ} / \mathrm{kg}]}\end{array}$ \\
\hline 1 & 111.1 & 5.985 & 500 & 195 & 2711.2 & 6.7386 & 78487.7 \\
\hline 2 & 105.5 & 5.859 & 489.5 & 195 & 2845.7 & 7.0490 & 79008.2 \\
\hline 3 & 5.555 & 0.1262 & 10.55 & 195 & 156.8 & 0.8411 & -520.5 \\
\hline 4 & 105.5 & 5.859 & 7.831 & 41.1 & 2299.2 & 7.3558 & 11680.9 \\
\hline 5 & 5.555 & 0.1262 & 0.1687 & -38.2 & -51.2 & 1.0161 & -1965.6 \\
\hline 6 & 111.1 & 5.985 & 8 & 40.3 & 2181.7 & 7.0389 & 9715.2 \\
\hline 7 & 2.097 & 0.1164 & 3.358 & 28.1 & 2552.4 & 8.5497 & 16.4 \\
\hline 8 & 2.097 & 0.1164 & 13.05 & 175.4 & 2831.8 & 8.6785 & 521.8 \\
\hline 9 & 5.555 & 0.1262 & 3.642 & 26.0 & 0.8 & 0.6310 & -1039.1 \\
\hline 10 & 5.555 & 0.1262 & 14.15 & 149.3 & 112.2 & 0.6853 & -510.3 \\
\hline 11 & 7.652 & 0.2426 & 27.2 & 160.6 & 857.4 & 2.8754 & 11.5 \\
\hline 12 & 7.652 & 0.2426 & 8 & 26 & 699.9 & 2.7656 & -942.4 \\
\hline 13 & 2.097 & 0.1164 & 3.838 & 26 & 2552.4 & 8.4882 & 54.9 \\
\hline 14 & 5.555 & 0.1262 & 4.162 & 26 & 0.81 & 0.6058 & -997.3 \\
\hline 15 & - & - & - & - & - & - & - \\
\hline 16 & 3278 & 182 & 8 & 36.5 & 173.8 & 0.5925 & 5733.4 \\
\hline 17 & 28.4 & 1.576 & 27.2 & 33 & 279.9 & 0.9166 & 317.3 \\
\hline 18 & 3307 & 183.5 & 8 & 41.5 & 174.7 & 0.5954 & 5941.1 \\
\hline 19 & 3307 & 183.5 & 101.3 & 41.7 & 174.9 & 0.5955 & 6257.5 \\
\hline 20 & 3202 & 177.7 & 101.3 & 25 & 104.9 & 0.3672 & 0 \\
\hline 21 & 26.84 & 1.49 & 27.2 & 25 & 104.9 & 0.3675 & -2.0 \\
\hline 22 & 3175 & 176.2 & 8 & 25 & 104.9 & 0.3675 & -549.8 \\
\hline 23 & 28.39 & 177.7 & 101.3 & 25 & 104.9 & 0.3672 & 0,00 \\
\hline 24 & 6.098 & 0.1563 & 27.2 & 33 & 234.0 & 1.0288 & -439.2 \\
\hline 25 & 28.4 & 1.576 & 8 & 41.5 & 279.9 & 0.9167 & 316.8 \\
\hline 26 & 3175 & 176.2 & 101.3 & 25 & 104.9 & 0.3672 & 0 \\
\hline 27 & 26.84 & 1.49 & 101.3 & 25 & 104.9 & 0.3672 & 0 \\
\hline 28 & 0.5427 & 0.03012 & 5.241 & 33 & 2562.2 & 8.3771 & 37.5 \\
\hline 29 & 5.555 & 0.1262 & 21.96 & 33 & 6.6 & 0.3109 & -476.7 \\
\hline 30 & 0.5427 & 0.03012 & 5.01 & 33.7 & 2562.2 & 8.3979 & 34.2 \\
\hline 31 & 5.555 & 0.1262 & 20.99 & 33.0 & 6.6 & 0.3194 & -490.8 \\
\hline 32 & 0.5427 & 0.03012 & 19.52 & 183.6 & 2847.3 & 8.5269 & 168.0 \\
\hline 33 & 5.555 & 0.1262 & 81.8 & 158.3 & 120.6 & 0.3738 & 52.5 \\
\hline 34 & 6.098 & 0.1563 & 101.3 & 162.5 & 363.3 & 1.0994 & 220.5 \\
\hline
\end{tabular}

Table 4 reports the exergy destructions/losses (EXD/L) of the system. The discrepancies in the results are explained in the following. First, not all the exergy destructions were accounted in the reference source. In addition, in [14] the exergy at the reference state $\varepsilon_{0}$ is assumed as the reference exergy of air, while in the present model the exergy at the reference state is calculated separately for each substance (water, carbon dioxide, steam and air). Finally, the present model tracks in detail the conditions of carbon dioxide, which was treated inside the $\mathrm{H}_{2} \mathrm{O} / \mathrm{CO}_{2}$ mixture in [14]. For these reasons, the resulting exergy efficiency is $71.2 \%$ in the present model, against $61.9 \%$ in [14].

The exergy Destruction/Loss reported in Table 4 were divided into 5 gross contributions, namely: $\mathrm{EXD}_{\mathrm{CT}}$ $\mathrm{EXD}_{\text {Turbine, }} \mathrm{EXD}_{\mathrm{D} 1}, \mathrm{EXL}_{\mathrm{CT}}, \mathrm{EXD}_{\text {Others }}$

The first three terms refer, respectively, to the exergy destruction at the cooling tower (CT), at the turbine and at the separator (D1), while the fourth term refers to the exergy loss at the cooling tower. Finally, EXD Others $_{\text {takes }}$ into account all other exergy Destructions/losses. All exergy destructions are calculated by differences of exergy fluxes (in-out). Exergy losses are considered as a complete loss of the exergy stream to the environment. Once all the exergy destruction/losses are calculated, the indirect exergy efficiency is given by:

$\eta_{x I n d}=1-\sum_{i=1}^{5} \frac{E X D L i}{E_{i n}}$

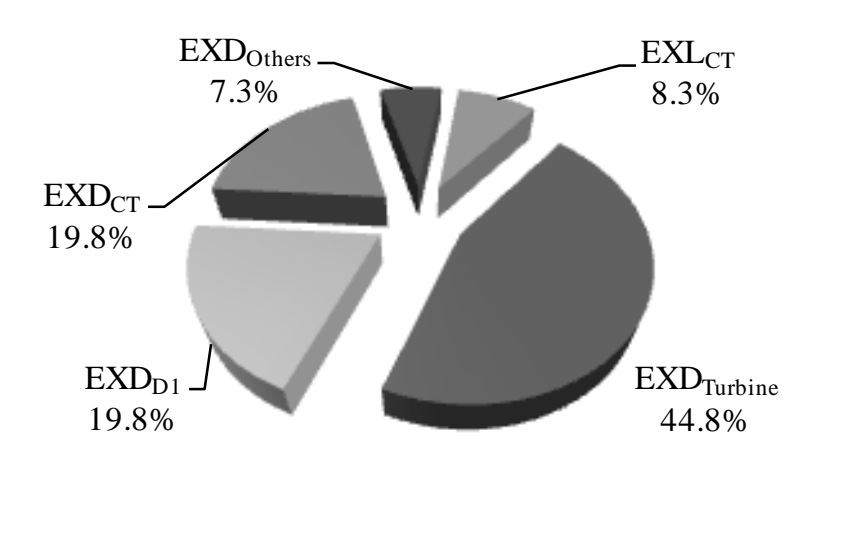

Figure 3. Exergy destruction/loss balance of the dry steam power plant. 
Table 4. Exergy Destructions/Losses.

\begin{tabular}{|c|c|c|c|c|}
\hline \multirow[t]{2}{*}{ Component } & \multicolumn{2}{|c|}{ Our model } & \multicolumn{2}{|c|}{ Bettagli and Bidini, [14] } \\
\hline & EXD/L [kW] & EXD/L [\%] & EXD/L [kW] & $\mathrm{EXD} / \mathrm{L}[\%]$ \\
\hline Turbine TV & 9656 & 43.8 & \multirow{2}{*}{12011} & \multirow{2}{*}{37.6} \\
\hline Turbine TC & 289.8 & 1.3 & & \\
\hline Separator D1 & 4374 & 19.8 & 7800 & 24.4 \\
\hline Compressor CV1 & 80.5 & 0.37 & \multirow{2}{*}{286} & \multirow{2}{*}{0.89} \\
\hline Compressor CC1 & 89.8 & 0.41 & & \\
\hline Separator D2 & 131.4 & 0.60 & 457 & 1.43 \\
\hline Compressor CV2 & 20.9 & 0.09 & \multirow{2}{*}{171} & \multirow{2}{*}{0.53} \\
\hline Compressor CC2 & 90.0 & 0.04 & & \\
\hline Lamination 13-7 & 38.5 & 0.17 & n.a. & n.a. \\
\hline Lamination 14-9 & 41.8 & 0.19 & n.a. & n.a. \\
\hline Lamination $28-30$ & 3.4 & 0.02 & n.a. & n.a. \\
\hline Lamination $29-31$ & 14.1 & 0.06 & n.a. & n.a. \\
\hline Lamination $17-25$ & 0.556 & 0.0 & n.a. & n.a. \\
\hline Lamination $26-22$ & 549.8 & 2.49 & n.a. & n.a. \\
\hline Lamination $27-21$ & 2,0 & 0.01 & n.a. & n.a. \\
\hline Mix 25-16 & 109.1 & 0.50 & \multirow{2}{*}{312} & \multirow{2}{*}{0.98} \\
\hline Pump & 73.9 & 0.34 & & \\
\hline Cooling tower & 4359 & 19.8 & 7593 & 23.80 \\
\hline Reinjection & 0 & 0.00 & 0 & 0 \\
\hline NGC discharge & 220.5 & 1.00 & 526 & 1.65 \\
\hline Cooling tower evaporation loss & 1898 & 8.61 & 2809 & 8.79 \\
\hline Total & 26525 & 100.00 & 31965 & 100.00 \\
\hline
\end{tabular}

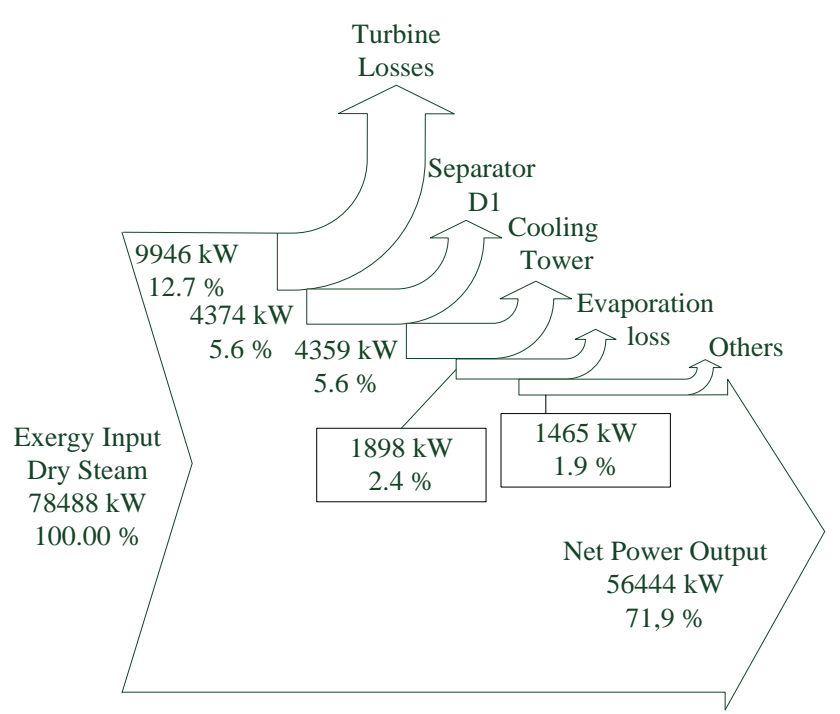

Figure 4. Grassmann exergy diagram.

Figure 3 collects the five terms previously described. The model confirms that the highest exergy destruction takes place in the turbine $\left(\mathrm{EXD}_{\text {Turbine }}\right)$, while the main exergy loss is located at the cooling tower where heat (i.e. exergy) is released to the ambient $\left(\mathrm{EXL}_{\mathrm{CT}}\right)$. Figure 4 shows the Grassmann exergy diagram (referred to the exergy input to the system, i.e. exergy at point 1). Cooling tower evaporation loss is the exergy lost due to the evaporation of a certain amount of cooling water mass flow rate. The water mass flow rate evaporated is calculated as the difference between the water mass flow rate in point 19 (CT inlet) and points 20 and 23, and it is equal to $77.4 \mathrm{~kg} / \mathrm{s}$.

\section{System Improvement}

As reported in Table 3, a consistent water flow rate is used to cool the system. In addition, the pressure loss of the cooling flow rate causes relevant exergy destruction (lamination 26-22, see Table 4). In order to reduce this exergy destruction, a Heller system is proposed. The Heller system, invented by Heller and Forgo, is represented in Figure 5 [18-19]. The main issue of the system is that the excess pressure head of water leaving the water-to-air heat exchangers is recovered by a hydro-turbine installed with a common shaft with the pump.

Table 5. Possible Power recovery using Heller Systems.

\begin{tabular}{llll}
\hline & Recovery & Recovery & \multicolumn{2}{c}{$\begin{array}{l}\text { Recovery } \\
\text { Turbine }\end{array}$} \\
& $\begin{array}{l}\text { Turbine } \\
\text { isentropic } \\
\text { efficiency=0.80 }\end{array}$ & $\begin{array}{l}\text { Turbine } \\
\text { isentropic } \\
\text { efficiency=0.75 }\end{array}$ & $\begin{array}{l}\text { isentropic } \\
\text { efficiency=0.7 }\end{array}$ \\
\hline Power recovered from process $17-25[\mathrm{~kW}]$ & 92.6 & 86.8 & 81.0 \\
Power recovered from process $27-21[\mathrm{~kW}]$ & 1.6 & 1.5 & 1.4 \\
Power recovered from process $26-22[\mathrm{~kW}]$ & 237.7 & 222.9 & 208.1 \\
Total power recovered from laminations $[\mathrm{kW}]$ & 331.9 & 311.2 & 290.5 \\
$\%$ circulation pump work & $85 \%$ & $80 \%$ & $74 \%$ \\
\hline
\end{tabular}




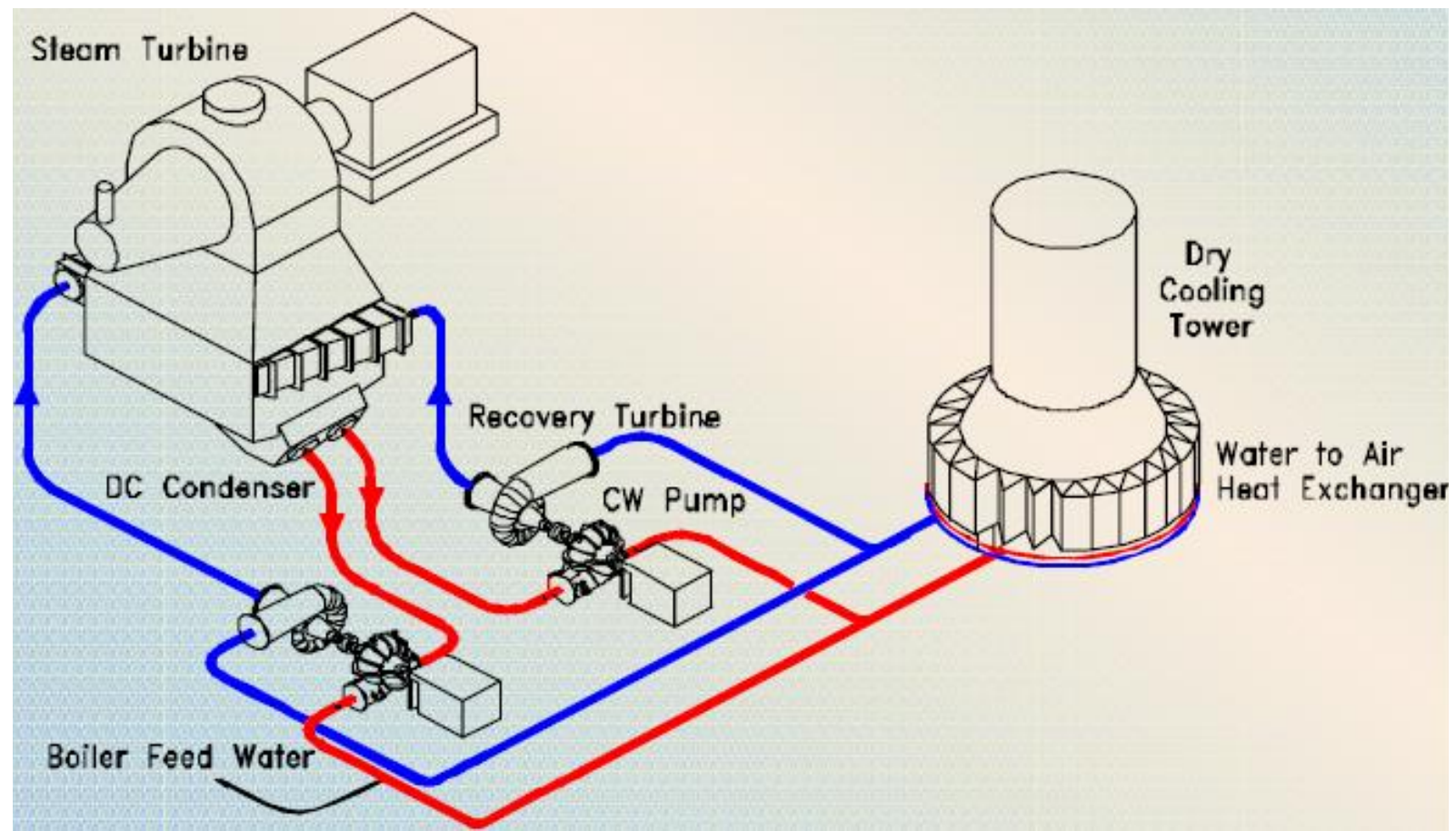

Figure 5. Advanced Heller System for indirect dry cooling tower [19]. (Figure is in color in the on-line version of the paper).

The work required by the circulation pump amounts to $390 \mathrm{~kW}$, and a relevant fraction could be recovered from laminations $17-25,27-21$ and 26-22 substituting each of them with a Heller system. Table 5 shows the power recovered from each lamination, for different values of the isentropic efficiencies of the hydro-turbines. The power recovered from process $27-21$ is negligible because of the small flow rate of the stream. The work recovered from the other two laminations can provide, in the best case, up to $85 \%$ of the power needed by the pump. It should be stressed that such a solution requires two separate hydraulic turbines, working on different hydraulic heads; however, the complication is worth the burden. It is clear that the largest advantage comes from power recovery applied to points 26-22.

\section{Conclusions}

In this paper a simplified thermodynamic model of a dry steam geothermal power plant is presented using direct expansion of a geo-fluid composed $95 \%$ of steam, and $5 \%$ of NCG. In the model, the geo-fluid flow is ideally separated in two flows, respectively water vapour flow and carbon dioxide flow. Mass and energy balances ensure consistency of the model, even if it does not include a detailed $\mathrm{H}_{2} \mathrm{O}-\mathrm{CO}_{2}$ mixture calculation process. The energy and exergy analysis provides results in general agreement with the reference case [14]. The energy efficiency of the system is $18,8 \%$ and the exergy efficiency is $71,2 \%$. For performance improvement, the possibility of recovering part of the pumping power through a Heller system was considered; the results show that it is possible to diminish the pumping work of almost $85 \%$. However, the energy and exergy efficiencies improve respectively of about $0,1 \%$ and $0,4 \%$, given that the power plant size (almost 60 MW) is largely higher than the energy recovered with the Heller system.

\begin{tabular}{|c|c|}
\hline EXD & exergy destruction, $\mathrm{kW}$ \\
\hline $\mathrm{EXD}_{\mathrm{CT}}$ & exergy destruction at cooling tower, $\mathrm{kW}$ \\
\hline $\mathrm{EXD}_{\mathrm{D} 1}$ & exergy destruction at first separator, $\mathrm{kW}$ \\
\hline $\mathrm{EXD}_{\text {Others }}$ & $\begin{array}{l}\text { exergy destruction at other compone } \\
\mathrm{kW}\end{array}$ \\
\hline $\mathrm{EXD}_{\text {Turbine }}$ & exergy destruction at turbine, $\mathrm{kW}$ \\
\hline EXL & exergy loss, $\mathrm{kW}$ \\
\hline $\mathrm{EXL}_{\mathrm{CT}}$ & exergy loss at cooling tower, $\mathrm{kW}$ \\
\hline $\mathrm{Geo}_{\text {rate }}$ & geothermal consumption, $\mathrm{kg} / \mathrm{kWh}$ \\
\hline$h$ & enthalpy, $\mathrm{kJ} / \mathrm{kg}$ \\
\hline HeatToPower & $\begin{array}{l}\text { ratio between the thermal pov } \\
\text { discharged and plant gross power }\end{array}$ \\
\hline$m$ & mass flow rate, $\mathrm{kg} / \mathrm{s}$ \\
\hline$p$ & pressure, bar \\
\hline$Q_{\mathrm{CT}}$ & thermal power discharged, $\mathrm{kW}$ \\
\hline$Q_{\text {geo }}$ & $\begin{array}{l}\text { thermal power supplied by } \\
\text { geothermal resource, } \mathrm{kW}\end{array}$ \\
\hline$s$ & entropy, $\mathrm{kJ} / \mathrm{kg} \mathrm{K}$ \\
\hline$T$ & temperature, ${ }^{\circ} \mathrm{C}$ \\
\hline$W_{\text {net }}$ & net power output, $\mathrm{kW}$ \\
\hline$W_{\mathrm{T}}$ & plant gross power, $\mathrm{kW}$ \\
\hline$X_{\mathrm{CO} 2}$ & $\begin{array}{l}\text { carbon dioxide percentage fractions i } \\
\text { mass }\end{array}$ \\
\hline$X_{\mathrm{H} 2 \mathrm{O}}$ & water percentage fractions in mass \\
\hline \multicolumn{2}{|l|}{ Greek symbols } \\
\hline$\varepsilon_{0}$ & specific exergy at reference state, $\mathrm{kJ} / \mathrm{kg}$ \\
\hline$\varepsilon$ & specific exergy, $\mathrm{kJ} / \mathrm{kg}$ \\
\hline$\eta$ & system efficiency \\
\hline$\eta_{\text {sep }}$ & separation efficiency \\
\hline$\eta_{\mathrm{xD}}$ & direct exergy efficiency \\
\hline$\eta_{\mathrm{xInd}}$ & indirect exergy efficiency \\
\hline
\end{tabular}

EXD

$\mathrm{EXD}_{\mathrm{D}}$

EXD $_{\text {Others }}$

$\mathrm{EXD}_{\text {Turbine }}$

EXL

$\mathrm{EXL}_{\mathrm{CT}}$

$\mathrm{GeO}_{\text {rate }}$

h
HeatToPower ratio between the thermal power
$m$
$Q_{\mathrm{CT}}$

specific exergy at reference state, $\mathrm{kJ} / \mathrm{kg}$ specific exergy, $\mathrm{kJ} / \mathrm{kg}$ separation efficiency indirect exergy efficiency

\section{Nomenclature}


Subscripts and superscripts

$\begin{array}{ll}\text { A } & \text { alternator } \\ C_{1} & \text { first compressor } \\ C_{2} & \text { second compressor } \\ \text { CT } & \text { cooling tower } \\ \mathrm{D}_{1} & \text { first separator } \\ \mathrm{D}_{2} & \text { second separator } \\ \text { in } & \text { inlet to the system (point 1) } \\ \mathrm{M}_{1} & \text { first separator } \\ \mathrm{M}_{2} & \text { second separator } \\ \text { NDCT } & \text { natural draft cooling tower } \\ \text { NGC } & \text { non-condensable gases } \\ \mathrm{P} & \text { pump } \\ \mathrm{T} & \text { turbine }\end{array}$

\section{References}

[1] R. DiPippo. Geothermal Power Plants: Principles, Applications, Case Studies and Environmental Impact, $2^{\text {nd }}$ Ed. Burlington, MA: Elsevier, 2008.

[2] J.E. Ahern, The Exergy Method of Energy System Analysis, Hoboken, NJ: John Wiley and Sons, 1980.

[3] M. Moran, Availability Analysis: A Guide to Efficient Energy Usage, Englewood Cliffs, NJ: Prentice-Hall, 1982.

[4] T. J. Kotas, The exergy method of thermal plant analysis, New York: Krieger, 1995.

[5] A. Bejan, G. Tsatsaronis, M. Moran, Thermal Design and Optimization, New York: Wiley Interscience, 1996.

[6] J. Szargut, D.R. Morris, F.R. Stewart, Exergy analysis of themal, chemical and metallurgical processes, London, UK: Taylor and Francis, 1998.

[7] M. Kanoglu, Exergy Analysis of a dual-level binary geothermal power plant. Geothermics, 31, 709-724, 2002.

[8] G. Bodvarsson, D.E. Eggers, The exergy of thermal power, Geothermics, 1, 93-95, 1972.
[9] R. DiPippo, D.F. Marcille, Exergy Analysis of Geothermal Power Plants, Geothermal Resources Council Transactions, 8, 47-52, 1984.

[10] R DiPippo, Second law assessment of binary plants generating power from low-temperature geothermal fluids, Geothermics, 33, 565-586, 2004.

[11] M. Yari, Exergetic analysis of various types of geothermal power plants, Renewable Energy, 35, 112-121, 2010.

[12] C. Coskun, Z. Oktay, I. Dincer, Performance evaluations of a geothermal power plant, Applied Thermal Engineering, 31, 4074-4082, 2011.

[13] H. Ganjehsarabi, A. Gungor, I. Dincer, Exergetic performance analysis of Dora II geothermal power plant in Turkey, Energy, 46, 101-108, 2012.

[14] N. Bettagli, G. Bidini, Larderello-FarinelloValleSecolo geothermal area: exergy analysis of the transportation network and of the electric power plants, Geothermics, 25, 3-16, 1996.

[15] Engineering Equation Solver, Academic Version V8.603, www.fchart.com, 2013.

[16] UNEP - United Nations Environment Program (Accessed 2011, February 21). Cooling towers: Energy Efficiency Guide for Industry in Asia Available: http://www.energyefficiencyasia.org/docs/ee_module s/Chapter-Cooling\%20Towers.pdf

[17] Italian Ministry of Environment, DLgs. 152/2006 attachment 5, Table 3.

[18] GEA EGI Co. Ltd. (Accessed 2011, February 21), GEA Heat Exchangers, Indirect dry cooling system (Heller system). Available: http://www.geaenergytechnology.com/opencms/opencms/egi/en/cool ing/drycooling/

[19] A. Balogh, Z. Szabo, The Advanced HELLER System - Technical Features and Characterisctics. EPRI Conf. on Advanced cooling Strategies/Technologies, Sacramento, CA, 2005. 